A C G

Rec. Nat. Prod. 15:6 (2021) 463-475

records of natural

publications

products

\title{
Di-, and Triterpenoids Isolation and LC-MS Analysis of Salvia marashica Extracts with Bioactivity Studies
}

\author{
Sibel Kıran Aydın $\oplus^{1}$, Abdülselam Ertaş $\oplus^{2}$, Mehmet Boğa $\oplus^{3}$, \\ Ebru Erol $\oplus^{4}$, Gülbahar Ö. Alim Toraman $\oplus^{5}$, Tuba Kuşman Sayğı $\odot^{6}$, \\ Belkıs Halfon $\oplus^{7}$ and Gülaçtı Topçu $\oplus^{5^{*}}$ \\ ${ }^{I}$ Health Sciences Institute, Bezmialem Vakif University, İstanbul, Türkiye \\ ${ }^{2}$ Dept. of Pharmacognosy, Faculty of Pharmacy, Dicle University, Diyarbakır, Türkiye \\ ${ }^{3}$ Dept. of Analytical Chemistry, Faculty of Pharmacy, Dicle University, Diyarbakır, Türkiye \\ ${ }^{4}$ Dept. of Analytical Chemistry, Faculty of Pharmacy, Bezmialem Vakif University, Istanbul, Türkiye \\ ${ }^{5}$ Dept. of Pharmacognosy, Faculty of Pharmacy, Bezmialem Vakif University, İstanbul, Türkiye \\ ${ }^{6}$ Dept. of Pharmacognosy, Faculty of Pharmacy, Van Yüzüncü Yil University, Van, Türkiye \\ ${ }^{7}$ Dept. of Chemistry, Faculty of Arts and Science, Bogazici University, Istanbul, Türkiye
}

(Received March 01, 2021; Revised May 02, 2021; Accepted May 03, 2021)

\begin{abstract}
In this study, dichloromethane, acetone, and methanol extracts of the aerial parts of the Salvia marashica plant which is an endemic species to Anatolia, were investigated. The total phenolic amounts of these extracts were determined as pyrocatechol equivalent and total flavonoids as quercetin equivalent. Antioxidant activity was determined by four complementary methods including inhibition of lipid peroxidation (by $\beta$ carotene color expression), DPPH free radical scavenging activity, ABTS cation radical scavenging activity and CUPRAC methods. Anticholinesterase activity of the extracts was investigated by the Ellman method against acetylcholinesterase (AChE) and butyrylcholinesterase (BChE) enzymes. Viability and cytotoxic activity tests were carried out on the fibroblast L929 cells and cytotoxic A549 lung cancer cells, respectively. The triterpenoids and diterpenoids constitute the major secondary metabolites of the $S$. marashica acetone and methanol extracts isolated by chromatographic methods. Their structures were determined based on spectroscopic methods, namely NMR and mass analyses. Ten terpenoids were obtained from either acetone or methanol extracts of the $S$. marashica. Seven of them were triterpenoids, elucidated as lupeol, lupeol-3-acetate, lup-12, 20(29)-diene, lup-20(29)-ene, $\alpha$-amyrin-tetracosanoate, oleanolic acid and ursolic acid besides a steroid $\beta$-sitosterol. Two abietane diterpenes, abieta-8,11,13-triene (1) and 18-acetoxymethylene-abieta-8,11,13-triene (2), were obtained from the acetone extract which were isolated from a Salvia species for the first time in the present study. The methanol extract was found to be very rich in rosmarinic acid determined by LC-MS/MS analysis.
\end{abstract}

Keywords: Salvia marashica; terpenoids; flavonoids; NMR; LC-MS/MS; bioactivity. @ 2021 ACG Publications. All rights reserved.

\section{Introduction}

Salvia species belongs to Lamiaceae (Labiatae) family plants which are rich in terpenoids. Over 900-1000 Salvia species grown throughout the world while there are over 100 Salvia species in Turkey, 53 of them being endemic to Turkey [1-3]. Secondary metabolites of Salvia species consist of

* Corresponding author: E-Mail: gtopcu@ bezmialem.edu.tr 


\section{Di-, and Triterpenoids of Salvia marashica}

terpenoids and steroids, flavonoids and other phenolic compounds. Salvia species can exhibit antiinflammatory [4], anticholinesterase [5], antiviral [6], hepatotoxic [7], cytotoxic-antitumor activities $[8,9]$ due to their constituents, particularly diterpenoids [5, 10] and triterpenoids [11] while their flavonoids showed antioxidant [12] and antimicrobial effects [13-15].

Salvia marashica A. İlçim, F. Celep \& Doğan is an endemic species that grows in rocky mountain slopes of Kahramanmaraş in south-eastern part of Turkey at an altitude of 850-1700 m. This species was first collected by Dr. Ahmet İlçim from the rocky slopes of Ahır Mountain, where the species is rare and local, and then introduced to the science world in 2009 [16]. The epithet name of the species is derived from the city Kahramanmaraş where the type sample was collected.

This plant is a perennial suffruticose herb usually flowers in April and May having lilac color and pleasant fragrance. Stems are many, ascending to erect with a 30-70 cm tall. S. marashica resembles three other endemic species of Turkey, S. rosifolia, S. huberi, and S. pisidica. However, it differs by its larger, serrate, and densely pilose terminal leaf segment, multicellular and black-headed glandular pilose hairs. There is a detailed morphological comparison of $S$. marashica with those three endemic species [16] in the literature. S. marashica flowers in April, the other two species (S. rosifolia and S. huberi) grow in eastern and north-eastern Anatolia, respectively. They flower from June to August while $S$. pisidica grows in western Anatolia.

\section{Materials and Methods}

\subsection{General Experimental Procedure}

All chemicals were used in analytical purity and were supplied from Sigma Aldrich and Merck companies. 1D and 2D NMR spectral analyses were obtained on a Varian ID-6508 $600 \mathrm{MHz}$ instrument using TMS as an internal standard for chemical shifts. The LCQ-Deca Ion Trap Mass Spectrometer was used for mass analyses of the pure compounds. Rotary Evaporator (Buchi L-100), and Microplate Elisa Reader (Eon Biotek-960) were also used as other equipment. The acetone and methanol extracts were analyzed by LC-MS/MS using a Nexera model Shimadzu UHPLC coupled to a tandem MS instrument to detect polar compounds (flavonoids and phenolics). The liquid chromatography instrument was equipped with LC-30AD binary pumps, DGU-20A3R degasser, CTO-10ASvp column oven, and SIL-30AC autosampler. The chromatographic separation was performed on a C18 reversed-phase Inertsil ODS-4 $(150 \mathrm{~mm} \times 4.6 \mathrm{~mm}, 3 \mu \mathrm{m})$ analytical column. The column temperature was fixed at $40^{\circ} \mathrm{C}$. The elution gradient consisted of mobile phase A (water, $5 \mathrm{mM}$ ammonium formate, and $0.1 \%$ formic acid) and mobile phase B (methanol, $5 \mathrm{mM}$ ammonium formate, and $0.1 \%$ formic acid). The gradient program with the following proportions of solvent $B$ was applied $\mathrm{t}(\mathrm{min}), \mathrm{B} \%:(0,40),(20,90),(23.99,90),(24,40),(29,40)$. The solvent flow rate was maintained at $0.5 \mathrm{~mL} / \mathrm{min}$, and the injection volume was settled as $4 \mu \mathrm{L}$.

\subsection{Plant Material}

The aerial parts of $S$. marashica was collected from South Anatolia (Kahramanmaraş, upper Ceyhan Valley, Ahır Mountain, Maksutlu village, at 1450 - 1600 m, in May 2014 by Dr. Serpil Demirci Kayıran and Dr. Tuba Kuşman Sayğı. It was identified by Dr. S. Demirci Kayıran, and a voucher specimen (ISTE No: 98045) is deposited in the Herbarium of Istanbul University.

\subsection{Extraction and Isolation}

The aerial parts of the collected plant were air-dried (2065 g). Powdered aerial parts of the plant were extracted with dichloromethane, acetone, and methanol, respectively. The dichloromethane extract is $19.0 \mathrm{~g}$, acetone extract is 9.7, $\mathrm{g}$ and methanol extract (SMM: S. marashica methanol extract) is $13.05 \mathrm{~g}$. Similarities of the contents of dichloromethane and acetone extracts were observed by TLC spots checking under UV lights at 254 and $366 \mathrm{~nm}$, and then occurring spots colors detection, followed by spraying cerium (IV) sulfate reagent on the TLC plate, then dried in an oven at $105^{\circ} \mathrm{C}$ for 5 minutes and the observation of the occurring spots colors. Due to the occurrence of the same spots 
on the TLC plate, the dichloromethane and the acetone extracts were combined, and was named as SMA. The mixed extract $(\mathrm{SMA}=28.7 \mathrm{~g})$ is named the acetone extract, which was fractionated on a silica gel column, and seven compounds were isolated from the acetone extract and then purified mainly by preparative thin-layer chromatographic technique. The column was eluted with petroleum ether, followed by a gradient of dichloromethane and acetone up to $100 \%$, respectively, and then $5 \%$ gradient of methanol up to $100 \%$. From the main column of the acetone extract, during the elution of petroleum ether (PE) and dichloromethane (DCM) (9:1), compound 1 was isolated and then purified and applied on Si-gel preparative TLC plates developing on a PE-DCM (85: 15) solvent system which afforded pure compound 1 (15.9 mg). From the fraction 29 of the acetone extract, compound 2 was obtained during elution of DCM-PE (6:4) as (89 mg). Compound 3 (Amyryltetracosanoate (Urs-12en-tetracosanoate)) was obtained from the methanol extract during the elution of the DCM-PE (1:1) solvent system as a white powder $(9,8 \mathrm{mg})$.

3-Acetyllupeol (Lup-20(29)-ene-3-acetate) (4) was also obtained from the main acetone extract by the elution of DCM-PE (6:4) from the fraction $27(25.6 \mathrm{mg})$. The other two lupane triterpenoids, both without any substituents, having two double bonds; lup-12,20(29)-diene (5) (72 $\mathrm{mg}$ ), and the other one having only a double bond between C-20 and C-29 which is called lup-20(29)ene (6) $(197.3 \mathrm{mg})$ were obtained from the acetone extract by DCM- PE (8:2) elution, and they were then purified in very small quantities by using Sephadex LH-20 column.

Lupeol (7) was obtained from both acetone and methanol extracts during the elution with 100 $\%$ chloroform (totally $600 \mathrm{mg}$ ) as white powder which was found to be the most abundant compound in the plant $[17,18]$. From the methanol extract, oleanolic acid (8) $(1.4 \mathrm{~g})$ and ursolic acid (9) $(1.6 \mathrm{~g})$ were also isolated, as well as $\beta$-sitosterol (10) $(38,2 \mathrm{mg})$. The yield $\%$ of each compound was calculated based on dried plant amount. According to the calculations, the yield $\%$ of the compounds are: $\mathbf{1}(0,00076 \%), \mathbf{2}(0.0041 \%), \mathbf{3}(0,00047 \%), \mathbf{4}(0.0012 \%), \mathbf{5}(0.0035 \%), \mathbf{6}(0.0095 \%), \mathbf{7}(1.4 \%), \mathbf{8}$ $(0.06779 \%), \mathbf{9}(0,07748 \%), \mathbf{1 0}(0.00184 \%)$.

\subsection{Determination of Cnolic Content and Flavonoid contents}

The total phenolic and flavonoid contents of the studied samples were calculated as equivalent to pyrocatechol and quercetin, respectively $[19,20]$.

\subsection{Antioxidant Activity}

$\beta$-Carotene-linoleic acid test system [21], ABTS cation radical [22], DPPH free radical [23], and CUPRAC (Cupper (II) ion reducing antioxidant capacity) [24] test methods were used to determine the antioxidant properties of the samples. In these four antioxidant test methods, BHT (Butylated Hydroxytoluene) was used as a reference compound.

\subsection{1. $\beta$-Carotene/Linoleic Acid Bleaching Assay}

$\beta$-Carotene $(0.5 \mathrm{mg})$ in $1 \mathrm{~mL}$ of chloroform was added into linoleic acid $(25 \mu \mathrm{L})$ and then tween 40 emulsifiers $(200 \mathrm{mg}$ ) mixture. After evaporating chloroform, $100 \mathrm{~mL}$ of distilled water saturated with oxygen was added and shaken; $160 \mu \mathrm{L}$ of this mixture was then transferred into different test tubes containing $40 \mu \mathrm{L}$ of the sample solutions at different concentrations. The emulsion was added to each tube, the zero time absorbance of the values was read at $470 \mathrm{~nm}$. The mixture was incubated for $2 \mathrm{~h}$ at $50{ }^{\circ} \mathrm{C}$ [21].

\subsubsection{ABTS Cation Radical Decolorization Assay}

ABTS $(7.0 \mathrm{mMol})$ in $\mathrm{H}_{2} \mathrm{O}$ was added to $2.45 \mathrm{mM}$ potassium persulfate to produce $\mathrm{ABTS}^{\cdot+}$ and the solution was stored in the dark at $25^{\circ} \mathrm{C}$ for $12 \mathrm{~h}$. The prepared solution was diluted with ethanol to get an absorbance of $0.700 \pm 0.025$ at $734 \mathrm{~nm}$. ABTS $^{++}$solution $(160 \mu \mathrm{L})$ was added to each sample solution at different concentrations. After $30 \mathrm{~min}$, the percentage inhibition at $734 \mathrm{~nm}$ was read for 


\section{Di-, and Triterpenoids of Salvia marashica}

each concentration relative to a blank absorbance (methanol) [22]. The following equation was used to calculate the scavenging capability of $\mathrm{ABTS}^{\cdot+}$ :

$$
\mathrm{ABTS}^{\cdot+} \text { scavenging effect }\left(\text { Inhibition \%) }=\frac{A_{\text {control }}-A_{\text {sample }}}{A_{\text {control }}} \times 100\right.
$$

\subsubsection{DPPH Free Radical Scavenging Assay}

DPPH $(0.1 \mathrm{mM} 160 \mu \mathrm{L})$ solution in methanol was added to $40 \mu \mathrm{L}$ of sample solutions in methanol at different concentrations. After 30 minutes, the absorbance values were read at $517 \mathrm{~nm}$. The DPPH free radical scavenging potential was calculated using the following equation:

$$
\text { DPPH scavenging effect }(\text { Inhibition } \%)=\frac{A_{\text {control }}-A_{\text {sample }}}{A_{\text {control }}} \times 100
$$

$A_{\text {Control }}$ is the initial concentration of the DPPH ${ }^{*}$

$A_{\text {Sample }}$ is the absorbance of the remaining concentration of $\mathrm{DPPH}^{*}$ in the presence of the extracts or positive controls [23].

\subsubsection{Cupric Reducing Antioxidant Capacity (CUPRAC)}

Samples were dissolved in distilled water to prepare their stock solution at $1000 \mu \mathrm{g} / \mathrm{mL}$ concentration. Aliquots of $61 \mathrm{~mL}$ of $1.0 \times 10^{-2} \mathrm{M}$ copper (II) chloride, $61 \mu \mathrm{L}$ of $\mathrm{NH}_{4} \mathrm{OAc}$ buffer $(1 \mathrm{M}$, $\mathrm{pH} 7.0$ ), and $61 \mu \mathrm{L}$ of $7.5 \times 10^{-3} \mathrm{M}$ neocuproine solution were mixed, $x \mu \mathrm{L}$ sample solution $(2.5,6.25$, 12.5 , and $25 \mu \mathrm{L})$ and $(67-x) \mu \mathrm{L}$ distilled water were added to make the final volume $250 \mu \mathrm{L}$. The tubes were stopped, and after $1 \mathrm{~h}$, the absorbance at $450 \mathrm{~nm}$ was measured against a reagent blank [24].

\subsection{Anticholinesterase Activity}

A spectrophotometric method developed by Ellman et al. (1961) was used to indicate the acetyl- and butyryl-cholinesterase inhibitory activities. Aliquots of $150 \mu \mathrm{L}$ of $100 \mathrm{mM}$ sodium phosphate buffer (pH 8.0), $10 \mu \mathrm{L}$ of sample solution, and $20 \mu \mathrm{L} \mathrm{BChE} \mathrm{(or} \mathrm{AChE)} \mathrm{solution} \mathrm{were} \mathrm{stirred}$ and incubated for $15 \mathrm{~min}$ at $25^{\circ} \mathrm{C}$, then DTNB $(10 \mu \mathrm{L})$ is added to the mixture. In the next step, by the addition of butyrylthiocholine iodide (or acetylthiocholine iodide) $(10 \mu \mathrm{L})$, the reaction was started. At the end, the final concentration of the tested solutions was $200 \mu \mathrm{g} / \mathrm{mL}$. BioTek Power Wave XS at 412 $\mathrm{nm}$ was used to monitor the hydrolysis of these substrates [25].

\subsection{Cytotoxic Activity (MTT Assay)}

MTT test was used to determine cytotoxicity. Cytotoxic activities were carried out to KÜBTAL (Kırıkkale University) with service procurement. This test is a sensitive method that uses tetrazolium salt of 3-[4,5-dimethylthiazol-2-yl]-2,5-diphenyltetrazolium bromide (MTT) to measure cell proliferation. If viability is calculated below $70 \%$, it means the sample has a cytotoxic potential. L929 Fibroblast cells and A549 cytotoxic cells were inoculated into 96 well plates at $1.0 \times 104$ cells per well. Cells were left to incubate for 24 hours. Samples were prepared at $1 \mathrm{mg} / \mathrm{mL}$. It was sterilized under UV and passed through a $0.20 \mu \mathrm{m}$ filter. $100 \mu \mathrm{g} / \mathrm{mL}, 50 \mu \mathrm{g} / \mathrm{mL}, 25 \mu \mathrm{g} / \mathrm{mL}, 12.5 \mu \mathrm{g} / \mathrm{mL}$ concentrations determined from the extracts were applied to the cells and incubated for 24 hours. As a control, only the nutrient medium was applied to the cells. At the end of 24 hours, the media in the wells were discarded, and $100 \mu \mathrm{L}$ of medium and $10 \mu \mathrm{L}$ of MTT solution were added to each well. After 3.5 hours of incubation at $37^{\circ} \mathrm{C}, 150 \mu \mathrm{L}$ of DMSO was added to the wells and incubated for 15 
minutes. The absorbance values of the 96-well plate were read at $570 \mathrm{~nm}$ in an ELISA plate reader to determine cell viability [26].

\subsection{Identification and Quantitation of Ohenolic Compounds by LC-MS/MS}

A previously established and validated LC-MS/MS method was applied to determine the phenolic contents in the acetone and methanol extracts of Salvia marashica. The validation parameters of this study were linearity, recovery, repeatability, limits of the detection (LOD), and limits of the quantification (LOQ). Detailed procedures of uncertainty evaluation have been previously reported in the literature [27]. Validation parameters are given in Table 7.

\section{Results and Discussion}

\subsection{Structure Elucidation}

In the present study, totally of 10 terpenoids were obtained from both acetone and methanol extracts of the $S$. marashica plant. Four of them were lupane triterpenoids (lupeol, 3-acetyl-lupeol, lup-12,20(29)-diene, lup-20(29)-ene) isolated from the acetone extract. The six compounds including two diterpenoids 1 and $\mathbf{2}$ and the other three triterpenoids; oleanolic acid, ursolic acid, and $\alpha$-amyrintetracosanoate, and a steroid $\beta$-sitosterol were obtained from the methanol extract of $S$. marashica [28$30]$.

From Salvia pomifera, a series of new abietane diterpenoids; pomiferins A-G, and two known abietane diterpenoids; ferruginyl-12-methyl ether and 18-hydroxy-8,11,13-trien-7-one, have been isolated [31, 32], some of them have similar structures to the compounds $\mathbf{1}$ and $\mathbf{2}$, but none of them was exactly showed the same structure [33]. In fact, compound $\mathbf{1}$ has been previously obtained by the acetylation of pomiferin A, isolated from $S$. pomifera [31]. The ${ }^{1} \mathrm{H}$ NMR and ${ }^{13} \mathrm{C}$ NMR data of compound 1 were not given in detail before. Therefore, its spectral data were now given based on 1D and 2 D NMR studies [Table 1], and HRMS. The main ion peak was observed as $[\mathrm{M}+1]^{+}$at $\mathrm{m} / \mathrm{z}$ 271.24097, corresponding to a molecular formula $\mathrm{C}_{20} \mathrm{H}_{31}$ which was verified structure of compound $\mathbf{1}$ as abieta-8,11,13-triene. Compound $\mathbf{2}$ was previously isolated from Nepeta teydea [34] which also belongs to the Lamiaceae family, its ${ }^{13} \mathrm{C}$ NMR data were also presented in Table 1.

Among lupane triterpenoids, lup-12,20(29)-diene, lup-20(29)-ene were isolated together. They could not be separated from each other on the Silica-gel column, and then by using Sephadex LH-20 on a small column, they were isolated from each other in a small quantity ( 2 and $3 \mathrm{mg}$, respectively). Based on our previous studies, it should be noted that lupane triterpenoids have been found in some Salvia species which are distributed in eastern and south-eastern Anatolia, rather than in western Anatolia, such as S. macrochlamys [17], S. kronenburgii [35, 36], S. trichoclada [18, 37]. All the compounds have been previously isolated from some Salvia species, except diterpenes (1) and (2).

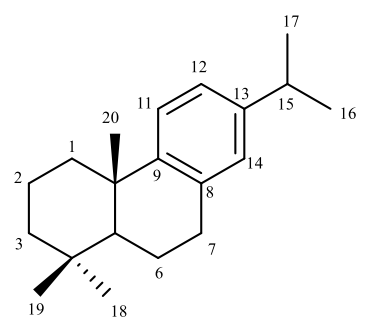

Abieta-8,11,13-triene (1)

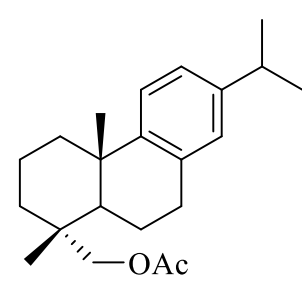

18-Acetoxymethylene-abieta-8,11,13-triene (2)

Figure 1. Structures of two abietane diterpenoids isolated from S. marashica 


\section{Di-, and Triterpenoids of Salvia marashica}

Table 1. NMR data for compounds 1 and $2\left(500 \mathrm{MHz}\right.$ in $\mathrm{CDCl}_{3}, \delta$ in ppm, and $J$ in $\mathrm{Hz}$

\begin{tabular}{|c|c|c|c|c|}
\hline \multirow[t]{2}{*}{ Position } & \multicolumn{2}{|c|}{ Compound 1} & \multicolumn{2}{|c|}{ Compound 2} \\
\hline & ${ }^{1} \mathbf{H}$ & ${ }^{13} \mathrm{C}$ & ${ }^{1} \mathbf{H}$ & ${ }^{13} \mathrm{C}$ \\
\hline $1 \alpha$ & $1.41 \mathrm{~m}$ & & $1.55 \mathrm{~m}$ & \\
\hline $1 \beta$ & $2.34 \mathrm{dt}(1.5$ and 12.7$)$ & 38.86 & $2.28 \mathrm{dt}(1.6$ and 12.8$)$ & 38.30 \\
\hline $2 \alpha$ & $1.73 \mathrm{~m}$ & & $1.74 \mathrm{~m}$ & \\
\hline $2 \beta$ & $1.87 \mathrm{~m}$ & 19.12 & $1.89 \mathrm{~m}$ & 18.90 \\
\hline $3 \alpha$ & $1.19 \mathrm{~m}$ & & $1.21 \mathrm{~m}$ & \\
\hline $3 \beta$ & $1.44 \mathrm{~m}$ & 41.14 & $1.41 \mathrm{~m}$ & 36.50 \\
\hline 4 & - & 30.51 & - & 31.70 \\
\hline 5 & $1.35 \mathrm{bd}(11.1)$ & 50.43 & 1.34 br d (11.8) & 44.20 \\
\hline $6 \alpha$ & $1.60 \mathrm{~m}$ & & $1.83 \mathrm{~m}$ & \\
\hline $6 \beta$ & $1.77 \mathrm{~m}$ & 19.34 & $1.88 \mathrm{~m}$ & 18.80 \\
\hline $7 \alpha$ & $2.82 \mathrm{~m}$ & 3051 & $2.83 \mathrm{~m}$ & \\
\hline $7 \beta$ & $2.92 \mathrm{dd}(4.2$ and 10.5) & 30.51 & $2.85 \mathrm{dd}(6.3$ and 10.8$)$ & 30.10 \\
\hline 8 & - & 134.95 & - & 134.30 \\
\hline 9 & - & 147.63 & - & 146.90 \\
\hline 10 & - & 37.53 & - & 37.23 \\
\hline 11 & $7.18 \mathrm{~d}(8.2)$ & 124.28 & $7.17 \mathrm{~d}(8.3)$ & 124.10 \\
\hline 12 & $6.98 \mathrm{dd}(1.2$ and 8.2$)$ & 123.78 & $6.99 \mathrm{dd}(1.75$ and 8.3$)$ & 123.70 \\
\hline 13 & - & 145.40 & - & 145.65 \\
\hline 14 & 6.88 br s & 126.81 & $6.89 \mathrm{br} \mathrm{s}$ & 126.85 \\
\hline 15 & 2.84 sept $(6.4)$ & 33.34 & $2.82 \operatorname{sept}(7.0)$ & 33.40 \\
\hline 16 & $1.24 \mathrm{~d}(6.4)$ & 24.01 & $1.22 \mathrm{~d}(7.0)$ & 23.80 \\
\hline 17 & $1.23 \mathrm{~d}(6.4)$ & 23.99 & $1.22 \mathrm{~d}(7.0)$ & 23.80 \\
\hline 18 & $0,94 \mathrm{~s}$ & 33.44 & $\begin{array}{l}3.68(11.0) \\
3.97(10.8)\end{array}$ & 72.30 \\
\hline 19 & $0,92 \mathrm{~s}$ & 21.63 & $0.93 \mathrm{~s}$ & 17.60 \\
\hline 20 & $1.22 \mathrm{~s}$ & 24.90 & $1.21 \mathrm{~s}$ & 25.20 \\
\hline $\mathrm{OCOCH} \underline{3}$ & - & - & $2.02 \mathrm{~s}$ & 21.50 \\
\hline $\mathrm{OCOCH}_{\underline{3}}$ & - & - & - & 171.00 \\
\hline
\end{tabular}

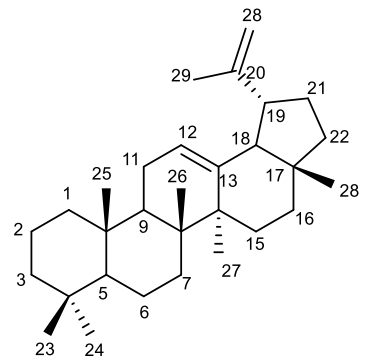

5

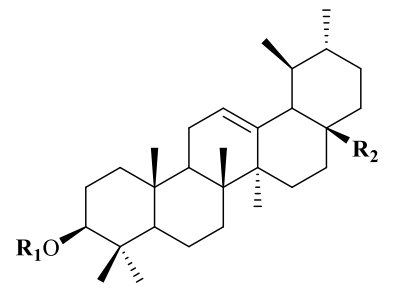

$\mathbf{R}_{\mathbf{1}}=\mathrm{H}, \mathrm{R}_{2}=\mathrm{COOH}$ 9<smiles>C=C(C)[C@@H]1CCC2(C)CC[C@H]3C4CCC5C(C)(C)CCC[C@]5(C)C4CCC3[C@]12C</smiles>

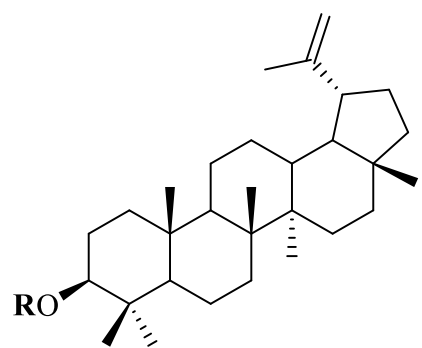
$\mathbf{R}=\mathrm{H} \quad 7$

$\mathbf{R}_{\mathbf{1}}=\mathrm{CO}\left(\mathrm{CH}_{2}\right)_{22} \mathrm{CH}_{3}, \mathrm{R}_{2}=\mathrm{CH}_{3} \mathbf{3}$<smiles>CC1=CCC2C(C(=O)O)(CCC23CCC2C(C)CCC(O)C23C)CC1C</smiles>

8<smiles>CCC(CCC1CCC2C3CC=C4C[C@H](O)CCC4(C)C3CCC12C)C(C)C</smiles>

10

Figure 2. Structures of the triterpenoids and a steroid isolated from S. marashica 


\subsection{Determination of Total Phenolic and Total Flavonoid Contents}

The total phenolic and total flavonoid contents of the two extracts were determined as equivalent to pyrocatechol and quercetin, respectively. The methanol (SMM) extract of the plant was fairly rich in total phenolic content compared to the acetone (SMA) extract. However, both extracts exhibited to have less amount flavonoids about 25-30 $\mu \mathrm{g}$ QEs/mg extract (Table 2).

Table 2. Results of total phenolic and total flavonoid contents of the S. marashica acetone (SMA) and the methanol (SMM) extracts

\begin{tabular}{|c|c|c|}
\hline Extracts & $\begin{array}{l}\text { Total phenolic content } \\
(\mu \mathrm{g} \text { PEs/mg extract })^{\mathrm{b}}\end{array}$ & $\begin{array}{c}\text { Total flavonoid content } \\
{(\mu \mathrm{g} \text { QEs/mg extract })^{\mathrm{c}}}^{\mathrm{c}}\end{array}$ \\
\hline SMA & $46.19 \pm 2.14$ & $25.13 \pm 1.15$ \\
\hline SMM & $172.38 \pm 3.37$ & $30.46 \pm 0.18$ \\
\hline
\end{tabular}

${ }^{\mathrm{b}}$ Phenolic content equivalent to pyrocatechol $\left(\mathrm{y}=0.021 \mathrm{x}+0.0396 \mathrm{R}^{2}=0.9993\right)$

'Flavonoid content equivalent to quercetin $\left(\mathrm{y}=0.1543 \mathrm{x}-0.0497 \mathrm{R}^{2}=0.9931\right)$

\subsection{Antioxidant Activity}

3.3.1. B-Carotene/Linoleic Acid Bleaching Assay, DPPH Free Radical Scavenging Assay, ABTS Cation Radical Decolorization Assay

Table 3. Results of antioxidant activity (inhibition \%) of the two extracts and standard BHT

\begin{tabular}{cccc}
\hline Extracts & $\boldsymbol{\beta}$-Carotene-Linoleic acid & $\begin{array}{c}\text { DPPH } \\
\text { free radical }\end{array}$ & ABTS cation radical \\
\hline SMA & $69.98 \pm 1.70$ & $208.95 \pm 3.65$ & $93.72 \pm 1.39$ \\
SMM & $67.83 \pm 1.15$ & $33.59 \pm 0.72$ & $15.04 \pm 0.08$ \\
BHT & $11.30 \pm 0.03$ & $58.86 \pm 0.50$ & $22.29 \pm 0.67$ \\
\hline
\end{tabular}

Values are given as the mean and standard deviation of three parallel measurements.

\subsubsection{Cupric Reducing Antioxidant Capacity (CUPRAC)}

The CUPRAC antioxidant determination method was studied at four different concentrations $(10,25,50,100 \mu \mathrm{g} / \mathrm{mL})$ (Table 4). In this method, the methanol extract was found to be more active than the acetone extract. However, it was determined that the methanol extract showed lower activity than the standard BHT.

Table 4. CUPRAC test assay of the two extracts and standard BHT

\begin{tabular}{ccccc}
\hline Extracts & $\mathbf{1 0} \boldsymbol{\mu g} / \mathbf{m L}$ & $\mathbf{2 5} \boldsymbol{\mu \mathbf { g }} / \mathbf{m L}$ & $\mathbf{5 0} \boldsymbol{\mu g} / \mathbf{m L}$ & $\mathbf{1 0 0} \boldsymbol{\mu g} / \mathbf{m L}$ \\
\hline SMA & $0.157 \pm 0.003$ & $0.318 \pm 0.020$ & $0.496 \pm 0.020$ & $0.745 \pm 0.050$ \\
SMM & $0.362 \pm 0.060$ & $0.751 \pm 0.020$ & $1.377 \pm 0.050$ & $2.378 \pm 0.140$ \\
BHT & $0.491 \pm 0.065$ & $1.117 \pm 0.098$ & $1.887 \pm 0.045$ & $3.337 \pm 0.184$
\end{tabular}

Values are given as mean and standard deviation of three parallel measurements.

\subsubsection{Anticholinesterase Activity}

According to the anticholinesterase activity results (Table 5), the extracts were tested at a concentration of $200 \mu \mathrm{g} / \mathrm{mL}$ which were not shown acetylcholinesterase enzyme inhibition. However, in the butyrylcholinesterase enzyme inhibition test, the methanol extract exhibited better activity rather than acetone extract with $74.59 \%$ inhibition which was close to the standard compound galantamine $(76.52 \%)$. 


\section{Di-, and Triterpenoids of Salvia marashica}

Table 5. Results of anticholinesterase activity of the two extracts

\begin{tabular}{ccc}
\hline Extracts & AChE (Inhibition \%) & BChE (Inhibition \%) \\
\hline SMA & N.A. & $50.63 \pm 1.93$ \\
SMM & N.A. & $74.59 \pm 3.27$ \\
Galantamine $^{\text {b }}$ & $76.08 \pm 0,39$ & $76.52 \pm 0.41$
\end{tabular}

Values are given as mean and standard deviation of three parallel measurements.

b: Reference, N.A.: Not Active

\subsubsection{Viability/Cytotoxic Activity}

Viability/Cytotoxicity test results are given in Figures 3 and $\mathbf{4}$. The cell viability on the fibroblast L929 cell lines of both extracts was found to be very similar and fairly high (90-80 \%) at four concentrations $(12.5,25.0,50.0$, and $100 \mu \mathrm{g} / \mathrm{mL})$.

In contrast, their cytotoxic activity was found to be fairly low on A549 lung cancer cell lines, and both extracts exhibited fairly close results to each other, given as $\mu \mathrm{g} / \mathrm{mL}$ at the four concentrations. The two extracts showed almost the same cell viability on the fibroblasts L929 cells. However, the acetone extract showed better cytotoxic activity than that of methanol extract, but none of the results showed a dose-dependent relationship.

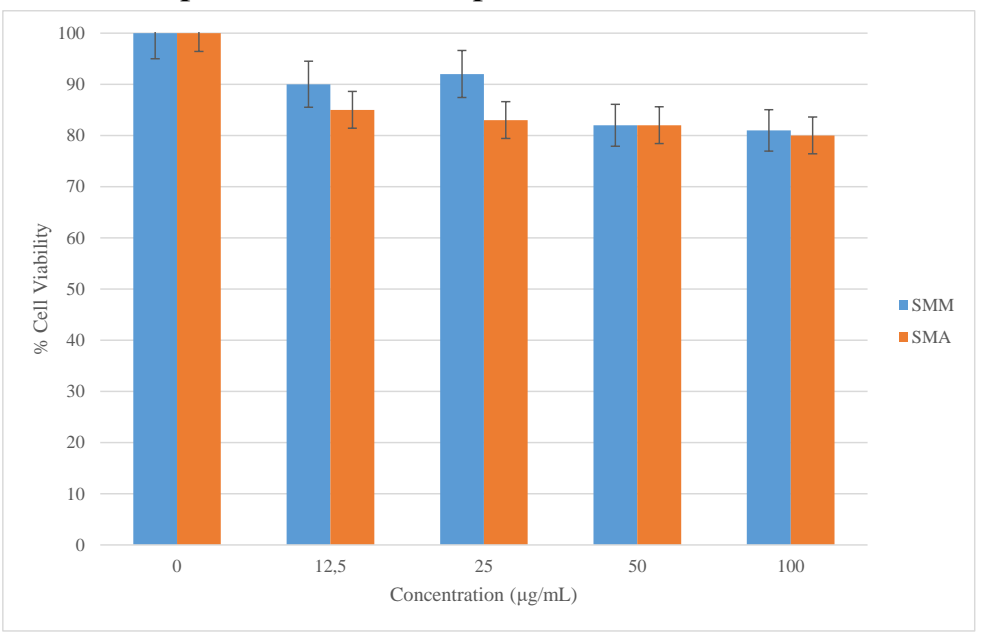

Figure 3. Cell Viability of the L929 cells after treatment with the extracts

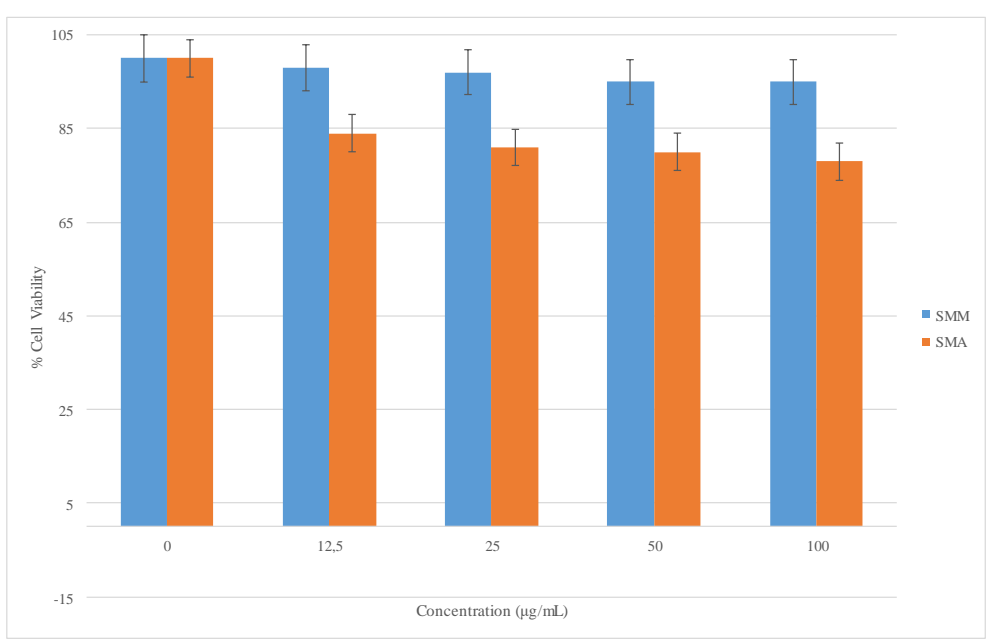

Figure 4. Cell Viability of the A549 cells after treatment with the extracts 


\subsection{5. $L C-M S / M S$}

In fact, the methanol extract was found to have fairly rich in total phenolic amounts as $(172,38$ $\mu \mathrm{g}$ PEs/mg extract) compared to the acetone extract (Table 2). LC-MS/MS qualitative and quantitative analyses results allowed us detection of 27 compounds; out of 15 are flavonoids, the rest of them being phenolics, particularly phenolic acids. Rosmarinic acid was found to be the highest phenolic compound $(33330,62 \pm 1534,89 \mu \mathrm{g}$ analyte/g) in the LC-MS/MS analysis of the methanol extract, which has strong antioxidant properties [38, 39, 40]. It is followed by trans caffeic acid $(752,65 \pm 35,39)$, tannic acid $(346,55 \pm 12,83)$, quinic acid $(333,45 \pm 12,31)$, and protocatechuic acid $(234,62 \pm 8,98)$ as $\mu \mathrm{g}$ analyte/g in the extracts. Total flavonoids amount in both extracts was found to be very small compared to the phenolics. Even, some flavonoids amounts were could not be measured, they have detected as the only trace. Another point, the presence of a high amount of rosmarinic acid in the methanol extract, created a problem for the detection of the compounds in small quantities (Table 6).
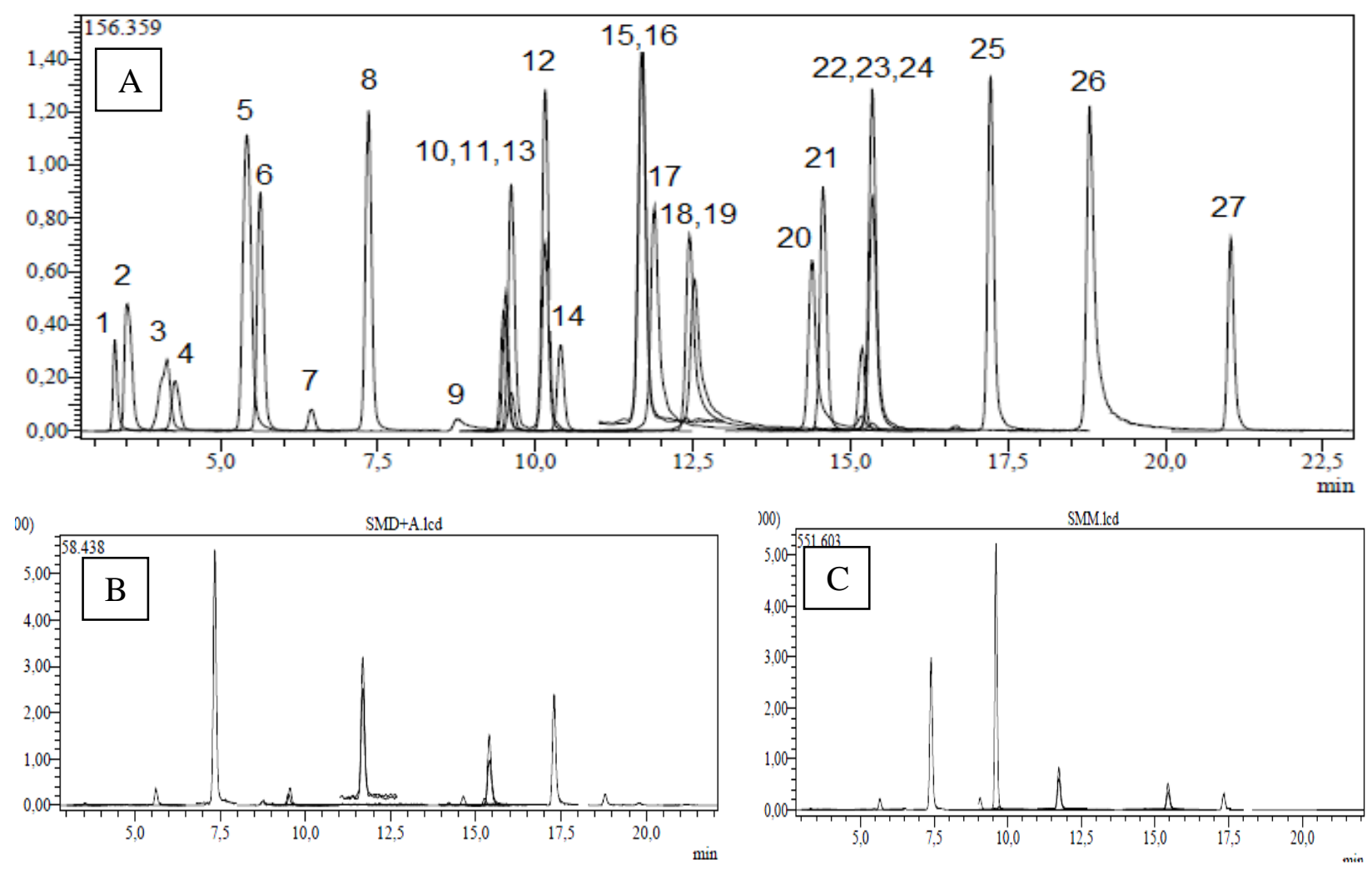

Figure 3. LC-MS/MS chromatograms of A: $250 \mathrm{ppb}$ standard mix, B: S. marashica acetone extract, C: $S$. marashica methanol extract

1: Quinic acid, 2: Malic acid, 3: tr-Aconitic acid, 4: Gallic acid, 5: Chlorogenic acid, 6: Protocatechuic acid, 7: Tannic acid, 8: tr- caffeic acid, 9: Vanillin, 10: p-Coumaric acid, 11: Rosmarinic acid, 12: Rutin, 13: Hesperidin, 14: Hyperoside, 15: 4-OH Benzoic acid, 16: Salicylic acid, 17: Myricetin, 18: Fisetin,19: Coumarin, 20: Quercetin, 21: Naringenin, 22: Hesperetin, 23: Luteolin, 24: Kaempferol, 25: Apigenin, 26: Rhamnetin, 27: Chrysin. 


\section{Di-, and Triterpenoids of Salvia marashica}

Table 6. Secondary metabolites of SMA and SMM Extracts by LC-MS/MS

\begin{tabular}{|c|c|c|c|c|}
\hline \multirow[t]{2}{*}{ Compounds } & \multirow{2}{*}{$\begin{array}{c}\text { Main } \\
\operatorname{Ion}(\mathbf{m} / \mathbf{z})^{a}\end{array}$} & \multirow[t]{2}{*}{$\mathbf{M S}^{2}(\text { Collision Energy })^{\mathbf{b}}$} & \multicolumn{2}{|c|}{$\begin{array}{c}\text { Amount } \\
{\text { ( } \mu \text { g analyte/g extract })^{c}}^{c}\end{array}$} \\
\hline & & & SMA & SMM \\
\hline Quinic acid & 190.95 & $85(22), 93(22)$ & $9.45 \pm 0.36$ & $333.45 \pm 12.31$ \\
\hline Malic acid & 133.05 & $115(14), 71(17)$ & $72.67 \pm 3.52$ & $223.04 \pm 11.35$ \\
\hline (E)-Aconitic acid & 172.85 & $85(12) .129(9)$ & $<\mathrm{LOD}$ & $<\mathrm{LOD}$ \\
\hline Gallic acid & 169.05 & $125(14), 79(25)$ & $1.31 \pm 0.02$ & $6.06 \pm 0.03$ \\
\hline Chlorogenic acid & 353.0 & $191(17)$ & $<\mathrm{LOD}$ & $54.57 \pm 2.51$ \\
\hline Protocatechuic acid & 152.95 & 109 (16),108 (26) & $40.29 \pm 2.01$ & $234.62 \pm 8.98$ \\
\hline Tannic acid & 182.95 & $124(22), 78(34)$ & $<\mathrm{LOD}$ & $346.55 \pm 12.83$ \\
\hline (E)-Caffeic acid & 178.95 & $135(15), 134(24), 89(31)$ & $139.53 \pm 8.57$ & $752.65 \pm 35.39$ \\
\hline Vanilin & 151.05 & $136(17), 92(21)$ & $100.76 \pm 4.98$ & $11.98 \pm 0.45$ \\
\hline$p$-Coumaric acid & 162.95 & $119(15), 93(31)$ & $42.79 \pm 1.62$ & $52.97 \pm 2.09$ \\
\hline Rosmarinic acid & 358.90 & $161(17), 133(42)$ & $288.07 \pm 13.76$ & $33330.62 \pm 1534.89$ \\
\hline Rutin & 609.10 & $300(37), 271(51), 301(38)$ & $<\mathrm{LOD}$ & $32.10 \pm 2.50$ \\
\hline Hesperidin & 611.10 & 303,465 & $5.97 \pm 0.09$ & $284.28 \pm 11.23$ \\
\hline Hyperoside & 463.10 & 300,301 & $<\mathrm{LOD}$ & $51.74 \pm 2.46$ \\
\hline 4-Hydroxybenzoic acid & 136.95 & 93,65 & $49.66 \pm 2.34$ & $138.78 \pm 7.03$ \\
\hline Sinapinic acid & 136.95 & $93,65,75$ & $48.96 \pm 2.29$ & $125.72 \pm 5.56$ \\
\hline Myricetin & 317.00 & $179,151,137$ & $<\mathrm{LOD}$ & $<\mathrm{LOD}$ \\
\hline Fisetin & 284.95 & 135,121 & $<\mathrm{LOD}$ & $<\mathrm{LOD}$ \\
\hline Coumarin & 146.95 & $103,91,77$ & $<\mathrm{LOQ}$ & $<\mathrm{LOQ}$ \\
\hline Quercetin & 300.90 & $179,151,121$ & $<\mathrm{LOQ}$ & $<\mathrm{LOQ}$ \\
\hline Naringenin & 270.95 & $151,119,107$ & $<\mathrm{LOQ}$ & $<\mathrm{LOQ}$ \\
\hline Hesperetin & 300.95 & $164,136,108$ & $9.27 \pm 0.45$ & $7.61 \pm 0.36$ \\
\hline Luteolin & 284.95 & $175,151,133$ & $33.27 \pm 1.59$ & $125.31 \pm 6.76$ \\
\hline Kaempferol & 284.95 & $217,133,151$ & $35.07 \pm 1.63$ & $135.55 \pm 7.21$ \\
\hline Apigenin & 268.95 & 151,117 & $37.91 \pm 1.87$ & $54.78 \pm 2.59$ \\
\hline Rhamnetin & 314.95 & $165,121,300$ & $<\mathrm{LOD}$ & $<\mathrm{LOD}$ \\
\hline Chrysin & 253.00 & $143,119,107$ & $<\mathrm{LOD}$ & $<\mathrm{LOD}$ \\
\hline
\end{tabular}

As a result, both extracts were found to be rich in terpenic compounds, particularly triterpenoids. Among triterpenoids, mainly lupeol, ursolic acid, and oleanolic acid were found to be high amounts in the plant. Thus, S. maraschica should be considered as a rich source for these triterpenoids with their cytotoxic and anti-inflammatory properties. Most of those triterpenoids have been previously obtained from several Salvia species by our group and investigated for their antioxidant and anticholinesterase activities. Particularly ursolic acid and oleanolic acid showed high and selective anticholinesterase activity [18]. Furthermore, this endemic plant was also found to be fairly rich in rosmarinic acid which is a well-known phenolic compound with high antioxidant and anticholinesterase activities [18, 37, 40] as well as anti-inflammatory, neuroprotective, antiviral, antimutagenic, anti-epileptic, antinociceptive, antidepressant, and anti-anxiolytic properties [41]. 
Table 7. Analytical parameters of LC-MS/MS method

\begin{tabular}{|c|c|c|c|c|c|c|c|c|c|}
\hline No & Analyte & $\mathbf{R T}^{\mathbf{a}}$ & $\begin{array}{l}\text { Linear Regression } \\
\text { Equation }\end{array}$ & $r^{2 \mathrm{~b}}$ & $\begin{array}{l}\text { RSD } \\
\%^{c}\end{array}$ & $\begin{array}{l}\text { Linearity } \\
\text { Range } \\
(\mathrm{mg} / \mathrm{L})\end{array}$ & $\begin{array}{l}\mathrm{LOD} / L O Q^{d} \\
(\mu \mathrm{g} / \mathrm{L})\end{array}$ & $\begin{array}{l}\text { Rec. } \\
(\%)\end{array}$ & $\mathbf{U}^{\mathrm{e}}$ \\
\hline 1 & Quinic acid & 3.36 & $y=33.6626 x+25132.9$ & 0.9927 & 0.0388 & $250-10000$ & $22.3 / 74.5$ & 103.3 & 4.8 \\
\hline 2 & Malic acid & 3.60 & $y=93.6102 x-5673.77$ & 0.9975 & 0.1214 & $250-10000$ & $19.2 / 64.1$ & 101.4 & 5.3 \\
\hline 3 & $(E)$-Aconitic acid & 4.13 & $y=79.2908 x-28416.2$ & 0.9933 & 0.3908 & $250-10000$ & $15.6 / 51.9$ & 102.8 & 4.9 \\
\hline 4 & Gallic acid & 4.25 & $y=358.069 x+26417.5$ & 0.9901 & 0.4734 & $25-1000$ & $4.8 / 15.9$ & 102.3 & 5.1 \\
\hline 5 & Chlorogenic acid & 5.29 & $y=48.9828 x+26779.7$ & 0.9932 & 0.1882 & $250-10000$ & $7.3 / 24.3$ & 99.7 & 4.9 \\
\hline 6 & $\begin{array}{l}\text { Protocatechuic } \\
\text { acid }\end{array}$ & 5.51 & $y=36.8568 x+6197.38$ & 0.9991 & 0.5958 & $100-4000$ & $25.8 / 85.9$ & 100.2 & 5.1 \\
\hline 7 & Tannic acid & 6.30 & $y=90.2704 x+30233.2$ & 0.9955 & 0.9075 & $100-4000$ & $10.2 / 34.2$ & 97.8 & 5.1 \\
\hline 8 & $(E)$-Caffeic acid & 7.11 & $y=1585.16 x+83957.5$ & 0.9942 & 1.0080 & $25-1000$ & $4.4 / 14.7$ & 98.6 & 5.2 \\
\hline 9 & Vanillin & 8.57 & $y=44.5478 x-574.867$ & 0.9995 & 0.4094 & $250-10000$ & $10.1 / 33.7$ & 99.2 & 4.9 \\
\hline 10 & $p$-Coumaric acid & 9.17 & $y=73.5303 x+27064.3$ & 0.9909 & 1.1358 & $100-4000$ & $15.2 / 50.8$ & 98.4 & 5.1 \\
\hline 11 & Rosmarinic acid & 9.19 & $y=18.0298 x-1149.86$ & 0.9992 & 0.5220 & $250-10000$ & $10.4 / 34.8$ & 101.7 & 4.9 \\
\hline 12 & Rutin & 9.67 & $y=51.8835 x+3841.66$ & 0.9971 & 0.8146 & $250-10000$ & $17.0 / 56.6$ & 102.2 & 5.0 \\
\hline 13 & Hesperidin & 9.69 & $y=195.773 x+105641$ & 0.9973 & 0.1363 & $250-10000$ & $21.6 / 71.9$ & 100.2 & 4.9 \\
\hline 14 & Hyperoside & 9.96 & $\begin{array}{l}y=0.978146 x+827.22 \\
1\end{array}$ & 0.9549 & 0.2135 & $100-4000$ & $12.4 / 41.4$ & 98.5 & 4.9 \\
\hline 15 & $\begin{array}{l}\text { 4-Hydroxy } \\
\text { benzoic acid }\end{array}$ & 11.38 & $y=635.003 x+54284.6$ & 0.9925 & 1.4013 & $25-1000$ & $3.0 / 10.0$ & 106.2 & 5.2 \\
\hline 16 & Salicylic acid & 11.39 & $y=915.178 x+72571.4$ & 0.9904 & 0.6619 & $25-1000$ & $4 / 13.3$ & 106.2 & 5.0 \\
\hline 17 & Myricetin & 11.42 & $y=54.2823 x+5414.67$ & 0.9991 & 2.8247 & $100-4000$ & $9.9 / 32.9$ & 106.0 & 5.9 \\
\hline 18 & Fisetin & 12.10 & $y=331.870 x+34409.0$ & 0.9988 & 2.4262 & $100-4000$ & $10.7 / 35.6$ & 96.9 & 5.5 \\
\hline 19 & Coumarin & 12.18 & $y=236.639 x+34370.3$ & 0.9924 & 0.4203 & $100-4000$ & $9.1 / 30.4$ & 104.4 & 4.9 \\
\hline 20 & Quercetin & 13.93 & $y=206.102 x+1693.14$ & 0.9995 & 4.3149 & $25-1000$ & $2.0 / 6.8$ & 98.9 & 7.1 \\
\hline 21 & Naringenin & 14.15 & $y=1100.55 x+39055.7$ & 0.9956 & 2.0200 & $25-1000$ & $2.6 / 8.8$ & 97.0 & 5.5 \\
\hline 22 & Hesperetin & 14.80 & $y=160.323 x+6545.07$ & 0.9961 & 1.0164 & $25-1000$ & $3.3 / 11.0$ & 102.4 & 5.3 \\
\hline 23 & Luteolin & 14.84 & $y=111.474 x+3057.10$ & 0.9992 & 3.9487 & $25-1000$ & $5.8 / 19.4$ & 105.4 & 6.9 \\
\hline 24 & Kaempferol & 14.85 & $y=20.9677 x+571.241$ & 0.9917 & 0.5885 & $25-1000$ & $2.0 / 6.6$ & 99.1 & 5.2 \\
\hline 25 & Apigenin & 16.73 & $y=543.793 x+18525.6$ & 0.9954 & 0.6782 & $25-1000$ & $0.1 / 0.3$ & 98.9 & 5.3 \\
\hline 26 & Rhamnetin & 18.41 & $y=110.091 x+632.444$ & 0.9994 & 2.5678 & $25-1000$ & $0.2 / 0.7$ & 100.8 & 6.1 \\
\hline 27 & Chrysin & 20.60 & $y=698.787 x+23531.7$ & 0.9965 & 1.5530 & $25-1000$ & $0.05 / 0.17$ & 102.2 & 5.3 \\
\hline
\end{tabular}

${ }^{\mathrm{a}} \mathrm{RT}$ : Retention time, ${ }^{\mathrm{b}} r^{2}$ : coefficient of determination, ${ }^{\mathrm{c} R S D}$ : relative standard deviation, ${ }^{\mathrm{d}} \mathrm{LOD} / \mathrm{LOQ}(\mu \mathrm{g} / \mathrm{L})$ :

Limit of detection/Limit of quantification, ${ }^{\mathrm{e}} \mathrm{U}(\%)$ : Percent relative uncertainty at $95 \%$ confidence level $(\mathrm{k}=2)$.

\section{Acknowledgments}

This study was carried out as a master thesis of Sibel Kiran Aydin at Faculty of Pharmacy, Bezmialem Vakif University. A part of the study has been done at the Faculty of Pharmacy, Dicle University, Diyarbakir. The authors thank Dr. Serpil Demir Kayiran for the collection and identification of the plant material.

\section{Supporting Information}

Supporting information accompanies with this paper on http://www.acgpubs.org/journal/recordsof-natural-products

\section{ORCID}

Sibel Kiran Aydın: 0000-0003-1810-5188

Abdülselam Ertaş: 0000-0002-2193-8386

Mehmet Boğa: 0000-0003-1810-5188

Ebru Erol: 0000-0001-6342-4298

Gülbahar Ö. Alim Toraman: 0000-0002-7816-7551

Tuba Kuşman Sayğı: 0000-0002-1771-1453

Belk1s Haflon: 0000-0001-5845-5081

Gülaçtı Topçu: 0000-0002-7946-6545 


\section{Di-, and Triterpenoids of Salvia marashica}

\section{References}

[1] F. Celep, E. Raders and B.T. Drew (2020). Two new hybrid species of Salvia (S. x karamanensis and $S$. $x$ doganii) from Turkey: Evidence from molecular and morphological studies, Turk. J. Bot. 44, 647-660.

[2] F. Celep (2010). Revision of the genus Salvia L. (Labiatae) in the mediterranean and the aegean geographic regions of Turkey, Biology Dept., Middle East Technical University.

[3] C. Hedge (1982). Salvia L. In: Flora of Turkey and the East Aegean Islands, Edinburgh Univ. Press, Edinburgh, pp.7

[4] D. Baricevic, S. Sosa, R. Della Loggia, A. Tubaro, B. Simonovska, A. Krasna and A. Zupancic (2001). Topical anti-inflammatory activity of Salvia officinalis L. leaves: the relevance of ursolic acid, $J$. Ethnopharmacol. 75,125-132.

[5] G. Topcu, A. Akdemir, U. Kolak, M. Ozturk, M. Boga, F. Bahadori and S.D.H. Cakmar (2020). Anticholinesterase and antioxidant activities of natural abietane diterpenoids with molecular docking studies, Curr. Alzheimer Res. 17, 269-284.

[6] M. Tada, K. Okuno, K. Chiba, E. Ohnishi and T. Yoshii (1994). Antiviral diterpenes from Salvia officinalis, Phytochemistry 35, 539-541.

[7] D.R. Gardner, K.E. Panter, B.L. Stegelmeier and C.A. Stonecipher (2021). Hepatotoxicity in cattle associated with Salvia reflexa diterpenes, including 7-hydroxyrhyacophiline, a new seco-clerodane diterpene, J. Agric. Food. Chem. 69, 1251-1258.

[8] G. Topcu, Z. Turkmen, J.K. Schilling, D.G.I. Kingston, J.M. Pezzuto and A. Ulubelen (2008). Cytotoxic activity of some anatolian Salvia extracts and isolated abietane diterpenoids, Pharm. Biol 46, 180-184.

[9] G. Topcu, U. Kolak, K. Balci and A. Ulubelen (2007). Structure elucidation of a new rearranged abietane diterpene from a biologically active plant Salvia eriophora, Nat. Prod. Commun. 2, 981-986.

[10] B. Culhaoglu, G. Yapar, T. Dirmenci and G. Topcu (2013). Bioactive constituents of Salvia chrysophylla Stapf, Nat. Prod. Res. 27, 438-447.

[11] A. Ulubelen, G. Topcu, H. Lotter, H. Wagner and C. Eris (1994). Triterpenoids from the aerial parts of Salvia montbretii, Phytochemistry 36, 413-415.

[12] B. Culhaoglu, A. Capan, M. Boga, M. Ozturk, T. Ozturk and G. Topcu (2017). Antioxidant and anticholinesterase activities of some dialkylamino substituted 3-hydroxyflavone derivatives, Med. Chem. 13, 254-259.

[13] A. Ulubelen, G. Topcu and C.B. Johansson (1997). Norditerpenoids and diterpenoids from Salvia multicaulis with antituberculous activity, J. Nat. Prod. 60, 1275-1280.

[14] B. Halfon, O. Cetin, G. Kokdil and G. Topcu (2019). Chemical investigation and bioactivity screening of Salvia cassia extracts, Rec. Nat. Prod. 13, 156-166.

[15] U. Kolak, G. Topcu, S. Birteksoz, G. Otuk and A. Ulubelen (2005). Terpenoids and steroids from the roots of Salvia blepharochlaena, Turk. J. Chem. 29, 177-186.

[16] A. Ilcim, F. Celep and M. Dogan (2009). Salvia marashica (Lamiaceae), a new species from Turkey, Ann. Bot. Fenn. 46, 75-79.

[17] G. Topcu, A. Ertas, U. Kolak, M. Ozturk and A. Ulubelen (2007). Antioxidant activity tests on novel triterpenoids from Salvia macrochlamys, Arkivoc 7, 195-208.

[18] B. Culhaoglu, S.D. Hatipoglu, A.A. Donmez and G. Topcu (2015). Antioxidant and anticholinesterase activities of lupane triterpenoids and other constituents of Salvia trichoclada, Med. Chem. Res. 24, 3831-3837.

[19] M.I.N. Moreno, M.I. Isla, A.R. Sampietro and M.A. Vattuone (2000). Comparison of the free radicalscavenging activity of propolis from several regions of Argentina, J. Ethnopharmacol. 71, 109-114.

[20] K. Slinkard and V. Singleton (1977). Total phenol analysis: automation and comparison with manual methods, AJEV 28, 49-55.

[21] H. Miller (1971). A simplified method for the evaluation of antioxidants, J. Am. Oil Chem. Soc. 48, 91.

[22] R. Re, N. Pellegrini, A. Proteggente, A. Pannala, M. Yang and C. Rice-Evans (1999). Antioxidant activity applying an improved ABTS radical cation decolorization assay, Free Radic. Biol. Med. 26, 1231-1237.

[23] M. Blois (1958). Antioxidant determinations by the use of a stable free radical, Nature, 181, 1199-1200.

[24] R. Apak, K. Guclu, M. Ozyurek and S.E. Karademir (2004). Novel total antioxidant capacity index for dietary polyphenols and vitamins $\mathrm{C}$ and $\mathrm{E}$, using their cupric ion reducing capability in the presence of neocuproine: CUPRAC method, J. Agric. Food Chem. 52, 7970-7981.

[25] G.L. Ellman and C.K. Diane (1961). A new and rapid colorimetric determination of acetylcholinesterase activity, Biochem. Pharmacol. 7, 88-95. 
[26] A. Ertas and I. Yener (2020). A comprehensive study on chemical and biological profiles of three herbal teas in Anatolia; rosmarinic and chlorogenic acids, S. Afr. J. Bot. 130, 274-281.

[27] A. Ertas, M.A. Yilmaz and M. Firat (2015). Chemical profile by LC-MS/MS, GC/MS and antioxidant activities of the essential oils and crude extracts of two Euphorbia species, Nat. Prod. Res. 29, 529-534.

[28] A. Ulubelen, U. Sonmez and G. Topcu (1997). Diterpenoids from the roots of Salvia sclarea, Phytochemistry 44, 1297-1299.

[29] G. Topcu, N. Tan, A. Ulubelen, D. Sun and W.H. Watson (1995). Terpenoids and flavonoids from the aerial parts of Salvia candidissima, Phytochemistry 40, 501-504.

[30] A. Ulubelen, G. Topcu, U. Sonmez, M.I. Choudhary and A. Ur-Rahman (1995). Abietane diterpenes from Salvia napifolia, Phytochemistry 40, 861-864.

[31] A. Ulubelen and G. Topcu (1992). Abietane diterpenoids from Salvia pomifera, Phytochemistry 31, 3949-3951.

[32] G. Topcu, A. Ulubelen and C. Eris (1994). Diterpenoids and triterpenoids of Salvia pomifera, Phytochemistry 36, 743-745.

[33] M.C. Chamy, M. Piovano, V. Gambaro, J.A. Garbarino and M. Nicoletti (1987). Dehydroabietane diterpenoids from Calceolaria-ascendens, Phytochemistry 26, 1763-1765.

[34] B.M. Fraga, T. Mestres, C.E. Diaz and J.M. Arteaga (1994). Dehydroabietane diterbenes from Nepeta teydea, Phytochemistry 35, 1509-1512.

[35] G. Topcu, Z. Turkmen, A. Ulubelen, J.K. Schilling and D.G.I. Kingston (2004). Highly hydroxylated triterpenes from Salvia kronenburgii, J. Nat. Prod. 67, 118-121.

[36] G. Topcu and A. Ulubelen (1999). Terpenoids from Salvia kronenburgii, J. Nat. Prod. 62, 1605-1608.

[37] O.L. Demirezer, P. Gurbuz, A. Kuruuzum-Uz, Z. Guvenalp, C. Kazaz and A.A. Donmez (2012). Chemical constituents of two sages with free radical scavenging activity, Nat. Prod. Commun. 7, 187 190.

[38] H. Yilmaz, S. Carikci, T. Kilic, T. Dirmenci, T. Arabaci and A.C. Goren (2017). Screening of chemical composition, antioxidant and anticholinesterase activity of section brevifilamentum of Origanum (L.) Species, Rec. Nat. Prod. 11, 439-455.

[39] Z. Ozer, S. Carikci, H. Yilmaz, T. Kilic, T. Dirmenci and A.C. Goren (2020). Determination of secondary metabolites of Origanum vulgare subsp. hirtum and O. vulgare subsp. vulgare by LCMS/MS, J. Chem. Metrology 14, 25-34.

[40] I. Erdogan Orhan, F. Sezer Senol, N. Ozturk, G. Akaydin, B. Sener (2012). Profiling of in vitro neurobiological effects and phenolics acids of selected endemic Salvia species, Food Chem. 132, 13601367

[41] M.G. Rahbardar and H. Hosseinzadeh (2020). Effects of rosmarinic acid on nervous system disorders: an updated review, NSAPCC 393, 1779-1795.

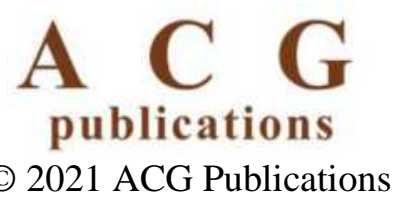

